\title{
Acute Toxicity and Lethality of Gladiolous psittacinus
}

\author{
*Moshood Abdullah Ishaq ${ }^{1}$, Ola-MudathirFausat Kikelomo ${ }^{1}$,Efere \\ MartinsObuotor $^{2}$, AbdulrahimMarufat Iyaboale ${ }^{3}$, Idris Adegbite Wasiu ${ }^{1}$ \\ ${ }^{I}$ Chemical sciencesDepartment, Crescent University Abeokuta \\ ${ }^{2}$ Biochemistry Department, Obafemi Awolowo University Ile-Ife \\ ${ }^{3}$ Faculty of Veterinary Medicine, Usman Danfodiyo University Sokoto
}

\begin{abstract}
The use of Gladiolouspsittacinusplant in traditional medicine is drastically increasing across the country Nigeria. This study was therefore conducted to evaluate the safety level of G. psittacinus using acute toxicity test (determination of median Lethal Dose; LD50) and the Brine shrimp lethality assay (BSLA). Histopathological analysis of the liver of rats orally administered with different dosages of G. psittacinus (1600, 2800 and $5000 \mathrm{mg} / \mathrm{kg}$ body weight) was also conducted. Results revealed amedian lethal dose (LD50) of the aqueous extract of G. psitticanus as $2116.60 \mathrm{mg} / \mathrm{kg}$ body weight. Similarly, the lethality concentration $\left(L C_{50}\right)$ of methanolic extract of G. psitticanus $(16.950 \mu \mathrm{g} / \mathrm{ml})$ was higher than the test standard, $\mathrm{K}_{2} \mathrm{Cr}_{2} \mathrm{O}_{7}(5.653 \mu \mathrm{g} / \mathrm{ml})$. The degree of lethality was also observed to be directly proportional to the concentration of the extracts. Histological studies also revealed that oral administration of G. psittacinus at 1600, 2800 and $5000 \mathrm{mg} / \mathrm{kg}$ body weight has the potential to cause some damages on the liver cells. Although G. psittacinus is a potential ethnomedicinal plant, its oral consumption is slightly toxic.
\end{abstract}

Keywords: Gladiolous psittacinus, brine shrimp, toxicity, medicinal plant,LD50, oral dose

\section{Introduction}

Herbs or plant parts such as leaves, stem, root, bulb, fruit, flowers and bark have been used in traditional medicine to assist the healing process during illness and diseases. The use of herbs in the history of man has been reported to date back to the time of the early men who had the crudest tools as implements (Kafaru, 1999) and continues to date by different cultures (Odhiamboet al., 2014). According to WHO (1993), about $80 \%$ of the world population relies on the use of traditional medicine, which is predominantly based on plant materials. These plant materials have been used in many domains including medicine, nutrition, flavouring, beverages, dyeing, repellents, fragrances, cosmetics, smoking, and other industrial purposes (Dahanukar et al., 2000; Exarchou et al., 2002).As reported by Farombi(2003), the biodiversity and presence of a wide array of bioactive phytochemicals and secondary metabolites in plants have made them a source of potential therapeutic agents against various diseases.

Several plants have been used worldwide for the treatment of numerous diseases.Some of such diseases include hypertension(Adjanohoun et al., 1985), cardiovasculardiseases (Ouedraogoet al.,2004), hepatic illness (Phillipson and Wright,1991), arthritis (Dongmo et al., 2003), diabetes(Al-Ghaithiet al., 2004) and malaria(Traoreet al., 2000). This surge in the useof herbal medicines was suggested by Okpuzoret al. (2009) to be due to theperceived failure of synthetic drugs in thetreatment of some chronic diseases, theside effects associated with most drugs andthe incidence of drug resistance especiallyamong the antibiotics family.In the south-western Nigeria alone, Soladoye et al. (2012) identified 132 plant species whichhave been tested and used by the herbalists in the treatment ofdiabetics. Similarly, Makinde et al. (2015) identified 107 plant species of medicinal plants used by the Badagry people of Lagos State Nigeria for thetreatment of obesity, asthma, diabetes and fertility. In Osun state, a total of 45 plant species was found to be useful in the treatment of diabetes (Mustafa et al., 2014).With the wide array of plant and plant parts used in traditional medicine by the people today, most of them are yet tobe documented and evaluated for safety and efficacy (Moshi et al., 2010). One of these plants is Gladiolous psittacinus. G. Psittacinusis an herbaceous and bulbous plant belonging to the family Iridaceous whichcomprises of about 1800 species grouped in 88 genuses (Francoiset al., 2013). According toAmehet al.(2011), G. Psittacinushas been used for various purposes in different parts of Nigeria.In the South West, the corms wereused in treating gonorrhoea, dysentery and otherinfectious conditions. In Hausa land a preparation madefrom Gladiolus corms called "rumanandoki" is used totreat dysentery in humans and horses.Gladiolus corms are also used in Benue State for the production of "Enyi" or "Umu" - a pleasantly sweet and very slightly sour, non-alcoholic beverage made from cereals (Ameh et al., 2011).

With the increasing use of G. Psittacinusamong various ethnic groups of Nigeria, there is the need to evaluate and document the safety and efficacy of the plant. This study was therefore conducted to evaluate the 
safety level of G. Psittacinususing acute toxicity test (determination of median Lethal Dose; LD50) and the Brine shrimp lethality assay (BSLA).

\section{Materials and Method}

\section{Plant Material}

Samples of fresh Gladiolouspsittacinus were purchased from the market at Ibadan, Oyo state and were authenticated at the Obafemi Awolowo University, Ile- Ife, Osun state. The bulbs were sliced, air dried and grinded into powder.

\section{Preparation of Crude Extract}

Two hundred grams of the bulb powder were macerated in $2000 \mathrm{ml}$ of $80 \%$ methanol. The mixture was stirred for four days using magnetic stirrer. The extract was filtered, concentrated to dryness using rotary evaporator at a temperature of $40^{\circ} \mathrm{C}$. Theextract yield was $2.65 \% \mathrm{w} / \mathrm{w}$.

\section{Experimental Animals}

Thirty six albino rats, weighing 180-200g were purchased from faculty of Veterinary Medicine, University of Ibadan and used for the studies. The rats were housed in metal cages in the animal holdings of Biochemistry Department, Crescent University and allowed to acclimatize for two weeks. The animals were kept and maintained under standard conditions ( $12 \mathrm{~h}$ light and dark cycle and room temperature at $25^{\circ} \mathrm{C}$ ) The rats were maintained on standard rats feed (Neimeth Livestock feed) ad libitum and allowed freeaccess to drinking water. Experimental procedure involving animals andtheir care were employed in conformity with guidelines for care and use of laboratoryanimals and the procedure approved by the Ethical Committee of Crescent University, Nigeria.

\section{Acute toxicity study (Determination of LD50)}

Determination of the median lethal dose (LD50) of the plant extract was done in two phases. In the first phase, nine rats were divided into three groups of three rats each and were treated with the methanol extract of the plant at dosages of 10,100 and $1000 \mathrm{mg} / \mathrm{kg}$ body weight orally. They were observed for 24 hours for signs of toxicity. In the second phase, nine rats were again divided into three groups of three rats each and were also treated with aqueous extract of Gladiolouspsittacinusat dosages of 1600,2800 and $5000 \mathrm{mg} / \mathrm{kg}$ body weight orally. The median lethal dose (LD50) was calculated as follows:

$\mathrm{LD} 50=\sqrt{\mathrm{D} 0} \mathrm{X} \mathrm{D} 100$

Where D0 = Dosage of 0 per cent mortality

D100 $=$ Dosage of 100 per cent mortality

\section{Brine Shrimp Lethality Assay (BSLA)}

The protocol of Miller and Tainter was adopted as described by Lilybeth and Olga (2013). Brine shrimp eggs were obtained from the ocean Nutrition, Belgium for this research work. Filtered, seawater was obtained from the bar beach Lagos state Nigeria for hatching the shrimp eggs. The seawater was put in a small plastic container (hatching chamber) with a partition for dark (covered) and light areas. Shrimp eggs were added into the dark side of the chamber while the lamp above the other side (light) will attract the hatched shrimp. Two days were allowed for the shrimp to hatch and mature as nauplii (larva). After two days, when the shrimp larvae are ready, $4 \mathrm{~mL}$ of the seawater was added to each test tube and 10 brine shrimps were introduced into each tube. Thus, there were a total of 30 shrimps per dilution. Then the volume was adjusted with seawater up to 5 $\mathrm{mL}$ per test tube. The test tubes were left uncovered under the lamp. The number of surviving shrimps were counted and recorded after 24 hours. Using probit analysis, the lethality concentration (LC50) was assessed at $95 \%$ confidence intervals. LC50 value of less than $1000 \mu \mathrm{g} / \mathrm{mL}$ is toxic while LC50 value of greater than 1000 $\mu \mathrm{g} / \mathrm{mL}$ is non-toxic. The percentage mortality $(\% \mathrm{M})$ was also calculated by dividing the number of dead nauplii by the total number, and then multiplied by $100 \%$.

\section{Histological evaluation of the liver}

The rats were sacrificed and the liver harvested for histological studies using standards methods. Briefly, a section of the organ was excised and fixed in $10 \%$ neutral formal saline for twenty - four (24) hours. This was followed by dehydration of tissues in series of graded alcohol $70 \%, 90 \%$ and 3 changes of absolute alcohol. The tissues were then cleared in chloroform. Impregnation and embedding of tissues using molten paraffin wax was followed by sectioning in a rotary microtome. Sections were 
prepared, stained with haematoxylin and eosin (H\&E) stain, and then mounted using DPX (Distrene 80 dibutylphthalate Xylene) for light microscopy and photomicrography.

\section{Results}

\section{Acute toxicity study and Determination of LD50}

Photomicrographs of hepatic tissue obtained from the histopathological evaluation of the rats used in the acute toxicity study of aqueous extract of Gladiolous psitticanus is shown in Plate 1. At the administration of $1600 \mathrm{mg} / \mathrm{kg}$ body weight of aqueous extract of $G$. psitticanus, moderate infiltration of inflammatory cells into the sinusoids and mild infiltration of inflammatory cells into the portal triads was observed. Administration of $2800 \mathrm{mg} / \mathrm{kg}$ body weight of aqueous extract of $G$. psitticanus revealed moderate congestions of vessels, dilation and congestion of sinusoids, moderate infiltration of inflammatory cells into the portal triads and mild infiltration into the sinusoids. However, mild infiltration of inflammatory cells into the portal triad and the sinusoids was evident in the hepatic tissues of rats administered with $5000 \mathrm{mg} / \mathrm{kg}$ body weight of aqueous extract of $G$. psitticanus.

The median lethal dose (LD50) of the aqueous extract of $G$. psitticanus was calculated as $2116.60 \mathrm{mg} / \mathrm{kg}$ body weight.

\section{Brine Shrimp Lethality Assay (BSLA)}

The results of the Brine Shrimp Lethality Assay, the percentage mortality and $\mathrm{LC}_{50}$ value are represented in Table 6. The lethality concentration $\left(\mathrm{LC}_{50}\right)$ of methanol extract of G. psitticanus $(16.950 \mu \mathrm{g} / \mathrm{ml})$ was higher than the test standard, $\mathrm{K}_{2} \mathrm{Cr}_{2} \mathrm{O}_{7}(5.653 \mu \mathrm{g} / \mathrm{ml})$. The degree of lethality was observed to be directly proportional to the concentration of the extracts with highest mortality recorded at $100 \mu \mathrm{g} / \mathrm{ml}$ for both methanolic extract of $G$. psitticanus ( $85 \%$ mortality) and the test standard, $\mathrm{K}_{2} \mathrm{Cr}_{2} \mathrm{O}_{7}$ (100\% mortality). However, percentage $(\%)$ mortality was lower in the methanolic extract of $G$. psitticanus than the test standard at the different levels of concentration used $(6.25,12.5,25,50$ and $100 \mu \mathrm{g} / \mathrm{ml})$.

\section{Discussions}

Although Gladiolouspsittacinushas been used for various medicinal purposes in different parts of Nigeria (Ameh et al., 2011), this study evaluated its safety and toxic effects.In this study, the median lethal dose (LD50) of the aqueous extract of G. psitticanus was calculated as $2116.60 \mathrm{mg} / \mathrm{kg}$ body weight. This LD50 value was described as slightly toxic according to Hodge and Sterner toxicity scale (Hodge and Sterner, 2005).Similarly, the histopathological evaluation of the liver revealed that the integrity of the liver cells may be compromised when administered with oral dose of aqueous $G$. psitticanus at toxic level. Therefore there is the need to carefully monitor the dose rate ofG.psitticanus for man, especially in the form of locally produced medicinal drinks.

Brine shrimp lethality bioassay (BSLA) was described as the simple bioassayuseful for screening large number of extractsin the drug discovery process from medicinal plants (Alluri et al., 2006).BSLA has beenused routinely in the primary screening of the crude extracts toassess the toxicity towards the brine shrimp, which could alsoprovide possible indication of toxicity of the test materials (Urmi et al., 2012). It was used to predict cytotoxicity properties of plant extracts and also possible presence of compounds with potential anticancer activity (Moshi at el, 2010) and anti-tumor (Ganatra et al., 2012). According to Kumar et al.(2011), a number of novel antitumor and pesticidal natural products have been isolated using this method. In this present study, the Brine Shrimp lethality concentration $\left(\mathrm{LC}_{50}\right)$ ofmethanolic extract of $G$. psitticanus was $16.950 \mu \mathrm{g} / \mathrm{ml}$. According to Meyer et al. (1982), $\mathrm{LC}_{50}$ value of less than $1000 \mu \mathrm{g} / \mathrm{mL}$ istoxic while LC50 value of greater than 1000 $\mu \mathrm{g} / \mathrm{mL}$ is non-toxic. Therefore, methanolic extract of $G$. psitticanus could be considered as containing active or

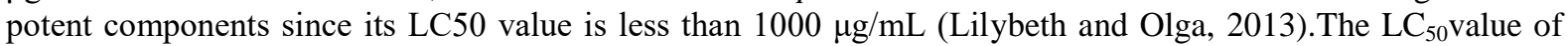
methanolic extract of $G$. psitticanus which is less than $20 \mu \mathrm{g} / \mathrm{ml}$ could make it a potential plant in the treatment of cancer. Plant extracts with $\mathrm{LC}_{50}$ values below $20 \mu \mathrm{g} / \mathrm{ml}$ have earlier been reported to have alikelihood of yielding anticancer compounds(Moshi et al., 2006; 2004). The $\mathrm{LC}_{50}$ value of methanolic extract of G. psitticanus $(16.950 \mu \mathrm{g} / \mathrm{ml})$ recorded in this study was however lower than those reported for some other plants such as Antiaris toxicaria $(38.2 \mu \mathrm{g} / \mathrm{ml})$, Bidensshimperi $(46.9 \mu \mathrm{g} / \mathrm{ml})$, Brideliamicrantha $(32.0 \mu \mathrm{g} / \mathrm{ml})$, Lantanatrifolia $(32.3 \mu \mathrm{g} / \mathrm{ml})$, Picralimanitida $(18.3 \mu \mathrm{g} / \mathrm{ml})$, Rubus rigidus $(19.8 \mu \mathrm{g} / \mathrm{ml})$, Moringa oleifera $(26.639 \mu \mathrm{g} / \mathrm{ml}$ and 36 .

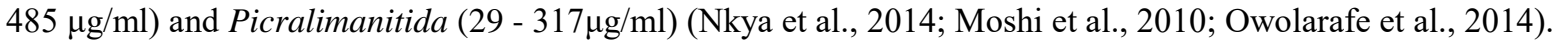




\section{Conclusion}

This study has shown that G. psitticanus is a potential plant for use in ethno-medicine and consumption by man and livestock. However, oral consumption of the extract of this plant is slightly toxic.
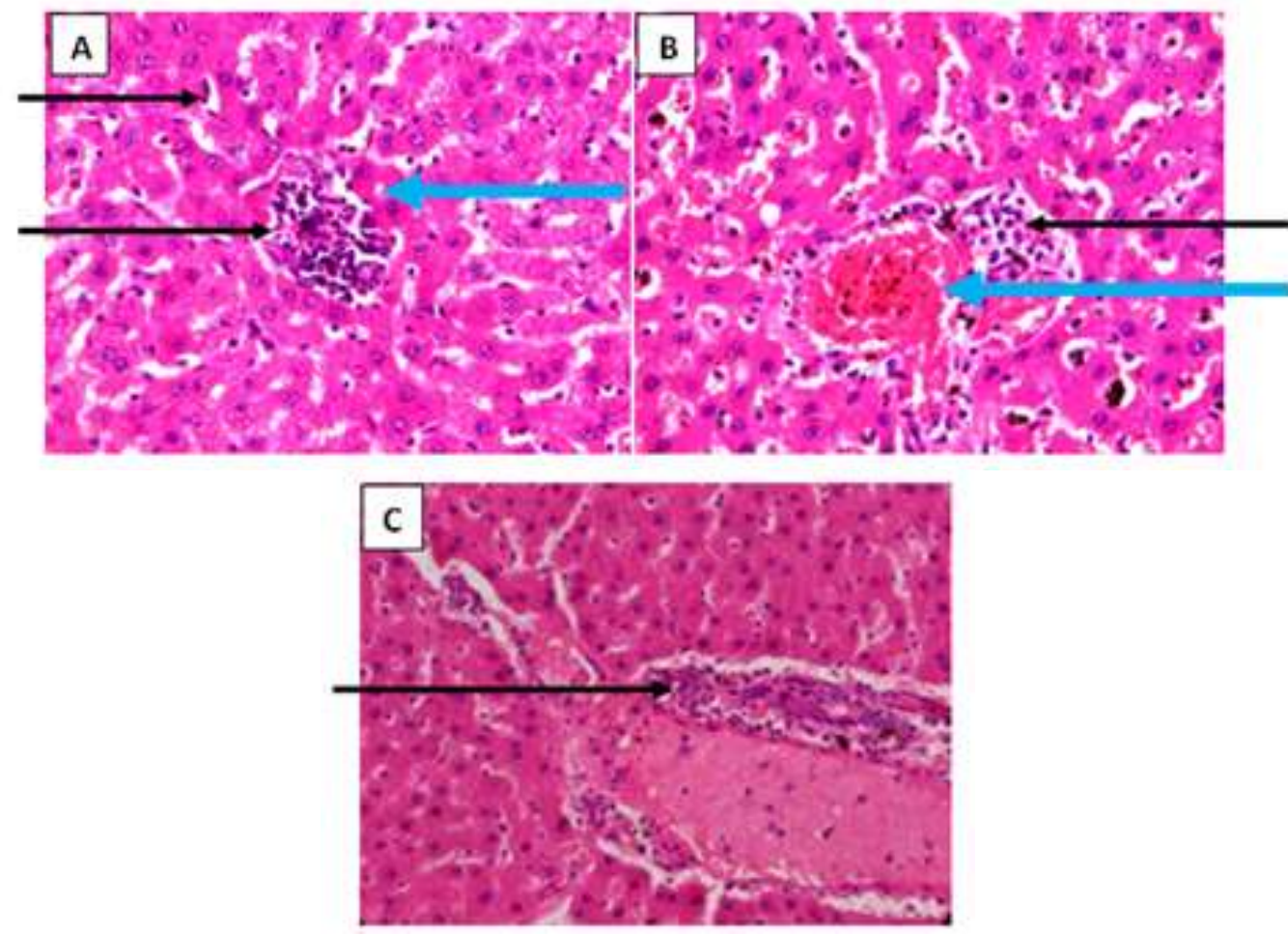

Plate 1: Photomicrographs of the hepatic tissues of rats used in Acute toxicity study of aqueous extract of Gladiolous psitticanus( $\mathrm{H} \& \mathrm{E}$ X400); $\mathrm{A}=1600 \mathrm{mg} / \mathrm{kg}$ body weight; moderate infiltration of inflammatory cells into the sinusoids (Zone 2) (black arrow) and mild infiltration of inflammatory cells into the portal triads (blue arrow). $\mathrm{B}=2800 \mathrm{mg} / \mathrm{kg}$ body weight; moderate congestions of vessels (blue arrow), moderate infiltration of inflammatory cells into the portal triads (black arrow) and mild infiltration into the sinusoids. $\mathrm{C}=5000 \mathrm{mg} / \mathrm{kg}$ body weight; mild infiltration of inflammatory cells into the portal triad (black arrow).

Table 6: The number of shrimp nauplii that survived after treatment with the extract of G. psitticanus, the percentage mortality and $\mathrm{LC}_{50}$ Value

\begin{tabular}{|c|c|c|c|c|c|c|}
\hline $\begin{array}{l}\text { Plant Methanolic } \\
\text { Extract }\end{array}$ & Concentration $\mu \mathrm{g} / \mathrm{ml}$ & \multicolumn{2}{|c|}{$\begin{array}{l}\text { Number of Surviving } \\
\text { Nauplii (after } 24 \mathrm{hrs} \text { ) }\end{array}$} & $\begin{array}{l}\text { Total Number of } \\
\text { Nauplii } \\
\text { survivors }\end{array}$ & \% Mortality & $\begin{array}{l}\text { LC }_{50} \text { Value } \\
(\mu \mathrm{g} / \mathrm{ml})\end{array}$ \\
\hline Control & Distilled water & 10 & 8 & 18 & 10 & \\
\hline \multirow{3}{*}{$\begin{array}{l}\text { Standard } \\
\mathrm{K}_{2} \mathrm{Cr}_{2} \mathrm{O}_{7}\end{array}$} & 12.5 & 3 & 2 & 5 & 75 & \\
\hline & 25 & 1 & 2 & 3 & 85 & 5.653 \\
\hline & 50 & 1 & 0 & 1 & 95 & \\
\hline \multirow{5}{*}{$\begin{array}{l}\text { Methanolic Extract } \\
\text { of Baaka }\end{array}$} & 6.25 & 7 & 8 & 15 & 25 & \\
\hline & 12.5 & 5 & 6 & 11 & 45 & \\
\hline & 25 & 3 & 3 & 6 & 70 & 16.950 \\
\hline & 50 & 2 & 3 & 5 & 75 & \\
\hline & 100 & 2 & 1 & 3 & 85 & \\
\hline
\end{tabular}

$\mathrm{T}=$ number of trials for each concentration.

\section{References}

[1]. Adjanohoun F.J., Ake A. L., Floret J.J., Guinko S., Koumare M. and Ahyi A.M. (1985).Contribution of the ethnobotanicals and flora in Mali to traditional medicine. Paris: Pharmacopia

[2]. Al-Ghaithi F., Mandouh R., El-Ridi M.R., Adeghate E., Amiri M.H. (2004).Biochemical effect of citrullus colocynthis in normal and diabetic rats. Mol Cell Biochem., 261: 143-9. 
[3]. Alluri V. K., Tayi V. N. R., Dodda S., Mulabagal V.,Hsin-Sheng T., and Gottumukkala V. S. (2006). Biological Screening of Medicinal Plants Collected from Eastern Ghats of India Using Artemia salina (Brine Shrimp Test)International Journal of Applied Science and Engineering. 4, 2: 115-125

[4]. Ameh, S. J., Obiageri O. Obodozie, Patrick O. Olorunfemi, Innocent E. Okoliko and Nelson A. Ochekpe (2011). Potentials of Gladiolus corms as an antimicrobial agent in food processing and traditional medicine Journal of Microbiology and Antimicrobials Vol. 3(1), pp. 8-12

[5]. Dahanukar S.A., Kulkarni R.A., Rege N.N. (2000). Pharmacology of medicinal plants and natural products. Ind J Pharm 32: S81S118.

[6]. Dongmo A.B., Kamanyi A., Dzikouk G., Nkeh C.B., Tan P.V., Nguelefack T., Nole T., Bopelet M. and Wagner H. (2003). Antiinflammatory and analgesic properties of the stem bark extract of Mitragyna ciliata (Rubiaceae) Aubrév. \& Pellegr. J Ethnopharmacol; 84:17-21.

[7]. Exarchou V., Nenadis N., Tsimidou M., Gerothanassis IP., Troganis A, Boskou D. (2002). Antioxidant activities and phenolic composition of extracts from Greek oregano, Greek sage and summer savory. J Agric Food Chem 50(19): 5294-5299.

[8]. Farombi E.O. (2003). African indigenous plants with chemotherapeutic potentials and biotechnological approach to the production of bioactive prophylactic agents Afr. J. Biotechnol. 2(12):662-671.

[9]. Francois M., Ana P. and Paulo C. (2013). Qualitative Phytochemical Screening and Antimicrobial Activity Evaluation of the Bulb Extracts of Gladiolus psittacinus Hook (Iridaceae) International Network Environmental Management Conflicts, 2(1), pp. 14-31

[10]. Ganatra, T., Joshi, U., Bhalodia, P., Desai, T. \& Tirgar, P. 2012. A panoramic view on pharmacognostic, pharmacological, nutritional, therapeutic and prophylactic values of Moringa oleifera lam. nternational Research Journal of Pharmacy 3, 1-7.

[11]. Hodge, A. and Sterner, B. (2005) Toxicity Classes. In: Canadian Center for Occupational Health and Safety.http://www.ccohs.ca/oshanswers/chemicals/id50.htm

[12]. Kafaru, E. (1999). Immense help from workshop. Elikaf services health Ltd. Lagos, 54-58.

[13]. Kumar S., Kumar V., Chandrashekhar MS. (2011). Cytotoxic activityof isolated fractions from methanolic extract of Asystasia dalzellianaleaves by brine shrimp lethality bioassay. Int J Pharm Pharm Sc.,3(3); 133-134

[14]. Lilybeth, F. O. and Olga M. N. (2013) brine shrimp lethality assay of the ethanolic extracts of three selected species of medicinal plants from Iligan, Philippines. Int. Research J. of Biological Sciences 2 (11) 74-77.

[15]. Makinde S.C., Ojekale A.B., Oshinaike T.S. and Awusinu T.S. (2015). An Ethnomedical and Ethnobotanical survey of Plants Herbal Therapy used for Obesity, Asthma, Diabetes and Fertility by the Badagry people of Lagos State. Nigeria Journal of Medicinal Plants Studies, 3(5): 01-06

[16]. Meyer B.N., Ferrigni N.R., Putnam J.E., Jacobsen L.B.,Nichols D.E., and McLaughlin J.L. (1982). Brine shrimp: Aconvenient general bioassay for active plant constituents,Plant Med, 45, 31-34

[17]. Moshi MJ, Innocent E, Magadula JJ, Otieno DF, Weisheit A, Mbabazi PK, Nondo RSO (2010). Brine Shrimp of Some Plants used as Traditional Medicine in Kagera Region, North West Tanzania. Tanzania Journal of Health Research 12, 63-67.

[18]. Moshi, M.J., Cosam, J.C., Mbwambo, Z.H., Kapingu, M. \& Nkunya, M.H.H. (2004) TestingBeyond Ethnomedical Claims: Brine Shrimp Lethality of Some Tanzanian Plants.Pharmaceutical Biology 42, 547-551

[19]. Moshi, M.J., Mbwambo, Z.H., Nondo, R.S.O., Masimba, P.J., Kamuhabwa, A., Kapingu,M.C., Thomas, P. \& Richard, M. (2006) Evaluation of ethnomedical claims and brineshrimp toxicity of some plants used in Tanzania as traditional medicines. AfricanJournal of Traditional, Complementary and Alternative Medicines 3, 48 - 58

[20]. Mustafa A.A., O.O. Fawibe, A.A. Ajiboye and D.A. Agboola (2014). Ethnobotanical Survey of Medicinal Plants Used in the Treatment of Diabetes in Irepodun Local Government Area of Osun State, Nigeria Greener Journal of Biological Sciences. 4 (2), pp. 059-068

[21]. Nkya, J.W., Erasto, P. and Chacha, M. (2014). Antimycobacterial and cytotoxicity activities of Moringa oleifera Lam extracts American Journal of Research Communication, 2(9): 108-120

[22]. Odhiambo J., Dossaji S., Lukhoba W. and Yenesew A. (2014). Phytochemical screening of Dierama cupuliflorum Klatt (Iridaceae). Journal of pharmacy Research;8;4;589- 592

[23]. Okpuzor, J., H. A. Ogbunugafor, G. K. Kareem 2009. Hepatic and hematologic effects of fractions of globimetula braunii in normal albino rats. Excli Journal 2009;8:182-189

[24]. Ouedraogo S, Ranaivo HR, Ndiaye M, Kabore ZI, Guissou PI, Bucher B, (2004). Cardiovascular properties of aqueous extract from Mitragyna inermis (wild). J Ethnopharmacol; 93:345-50.

[25]. Owolarafe T. A., Dosunmu S. O., Yakubu M. T., Lawal A. T., Akolade J. O., Muhammed M. B., Ononamadu C. J. (2014). Phytochemical investigation and brine shrimp lethality assay of extracts of picralima nitida (apoceanacea)staph. Seeds. Asian Journal of Pharmacology and Toxicology 02 (03); 11-15.

[26]. Phillipson J.D. and Wright C.W. (1991). Can ethnopharmacology contribute to the development of antimalarial agents? J. Ethnopharmacol; 32:155-65.

[27]. Soladoye, M. O., Chukwuma, E. C. and Owa, F. P. (2012). An 'Avalanche' of Plant Species for the Traditional Cure of Diabetes mellitus in South-Western Nigeria J. Nat. Prod. Plant Resour., 2 (1): 60-72

[28]. Traore F., Gasquet M., Laget M., Guiraud H., Giorgio C.D., Azas N., Doumbo O., Timon-David P. (2000). Toxicity and genotoxicity of antimalarial alkaloid rich extracts derived from Mitragyma inermis O. Kuntze and Nuclea latifolia. Phytother Res., 4:608-11.

[29]. Urmi, K.F.,Masum, N.H., Zulfiker, A.H.,Hossain, K. and Hamid, K. (2012). Comparative Anti-microbial activity and brine shrimp lethalitybioassay of different parts of the plant Moringa oleifera lam. Journal of Applied Pharmaceutical Science, 2 (12), 085-088

[30]. WHO (1993). Regional Office for Western Pacific, research guidelines for evaluating the safety and efficacy of herbal medicines. Manila. 